\title{
An Ongoing Debate Regarding the Etiology of Obsessive-Compulsive Disorder: Latent Toxoplasma gondii Infection
}

\section{Obsesif Kompulsif Bozuklug̃un Etiyolojisine İlișkin Süregiden Bir Tartıșma: Latent Toxoplasma gondii İnfeksiyonu}

\author{
Mümtaz Cem șiRiN'(IiD), Faruk KILIÇ²(ID), Arif DEMirDAȘ²(iD), Buket CiCiOG̃LU ARIDOG̃AN'(iD), \\ Emel SESLi ÇETIN'(IiD), Bektaș ÖNAL²(iD)
}

\footnotetext{
${ }^{1}$ Department of Medical Microbiology, Süleyman Demirel University Faculty of Medicine, Isparta, Turkey

${ }^{2}$ Department of Psychiatry, Süleyman Demirel University Faculty of Medicine, Isparta, Turkey
}

Cite this article as: Şirin MC, Kıllç F, Demirdaş A, Cicioğlu Arıdoğan B, Sesli Çetin E, Önal B. An ongoing debate regarding the etiology of obsessive-compulsive disorder: latent Toxoplasma gondii infection. FLORA 2021;26(2):277-84.

\begin{abstract}
Introduction: The hypothesis that Toxoplasma gondii may be responsible for psychiatric disorders due to its neurotropic nature and the ability of modulating neurotransmitter systems has been frequently discussed in recent years. The aim of the study was to investigate T. gondii seroprevalence in patients with obsessive-compulsive disorder and healthy volunteers living in Isparta region of Turkey, and to assess the possible relationship between $T$. gondii and obsessive-compulsive disorder.
\end{abstract}

Materials and Methods: Thirty-eight patients with obsessive-compulsive disorder and 48 healthy controls were enrolled in the study. Sociodemographic data, probable risk factors for T. gondii infection and clinical features were evaluated. Serum anti-T.gondii IgM and IgG levels were determined by using chemiluminescence immunoassay method (Roche Cobas e601 analyzer, Roche Diagnostics, Mannheim, Germany).

Results: Anti-T.gondii IgG seropositivity rates were found to be $15.8 \%$ and $18.8 \%$ in the patient group and the control group, respectively. No statistically significant association was detected between T. gondii IgG seropositivity and obsessive-compulsive disorder ( $p=$ 0.719). In the study population, advanced age, low education level, low socioeconomic status, living in a rural region and consumption of unwashed raw vegetable or fruit were found to be the significant risk factors for T. gondii infection $(p<0.05)$.

Conclusion: Our preliminary findings do not support the hypothesis that T. gondii infection is related to obsessive-compulsive disorder. Further comprehensive studies are required to confirm our results.

Key Words: Obsessive-compulsive disorder; Toxoplasma gondii; Seroprevalence 
ÖZ

\section{Obsesif Kompulsif Bozuklug̃un Etiyolojisine iliș̦kin Süregiden Bir Tartıșma: Latent Toxoplasma gondii İfeksiyonu}

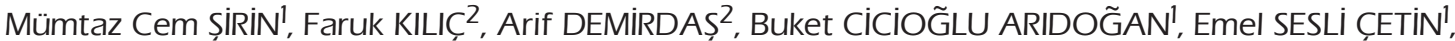 Bektas ÖNAL ${ }^{2}$}

1 Süleyman Demirel Üniversitesi Tıp Fakültesi, Tıbbi Mikrobiyoloji Anabilim Dalı, Isparta, Türkiye

2 Süleyman Demirel Üniversitesi Tıp Fakültesi, Ruh Sag̃lı̃̆ı ve Hastalıkları Anabilim Dalı, Isparta, Türkiye

Giriş: Son yıllarda, Toxoplasma gondii'nin nörotropik özelliği ve nörotransmitter sistemlerini modüle etme yeteneği nedeniyle psikiyatrik bozukluklardan sorumlu olabileceği hipotezi sıkça tartışılmaktadır. Çalıșmanın amacı, Isparta bölgesinde yaşayan obsesif kompulsif bozukluğu olan hastalarda ve sağlıkı gönüllülerde T. gondii seroprevalansını araştırmak ve T. gondii ile obsesif kompulsif bozukluk arasındaki olası ilişkiyi değerlendirmektir.

Materyal ve Metod: Çalışmaya obsesif kompulsif bozukluğu olan 38 hasta ve 48 sağılılı kontrol alındı. Sosyodemografik veriler, T. gondii infeksiyonu için olası risk faktörleri ve klinik özellikler değerlendirildi. Serum anti-T. gondii lgM ve IgG düzeyleri kemilüminesans immunoassay yöntemi (Roche Cobas e601 analyzer, Roche Diagnostics, Mannheim, Almanya) kullanılarak belirlendi.

Bulgular: Anti-T. gondii lgG seropozitiflik oranları hasta grubunda ve kontrol grubunda sırasıly \%15.8 ve \%18.8 olarak bulundu. T. gondii IgG seropozitifliği ile obsesif kompulsif bozukluk arasında istatistiksel olarak anlamlı bir ilişki saptanmadı $(p=0.719)$. Çalıșma popülasyonunda, ileri yaş, düşük eğitim düzeyi, düşük sosyoekonomik durum, kırsal bölgede yaşama ve yıkanmamış çiğ sebze veya meyve tüketimi T. gondii infeksiyonu için anlamlı risk faktörleri olarak bulundu $(p<0.05)$.

Sonuç: Bulgularımız, T. gondii infeksiyonunun obsesif kompulsif bozuklukla ilişkili olduğu hipotezini desteklememektedir. Sonuçlarımızın doğrulanması için daha kapsamlı çalışmalara ihtiyaç bulunmaktadır.

Anahtar Kelimeler: Obsesif kompulsif bozukluk; Toxoplasma gondii; Seroprevalans

\section{INTRODUCTION}

Obsessive-compulsive disorder is a common, chronic and disabling neuropsychiatric disorder characterized by uncontrollable recurrent intrusive thoughts, urges or images and repetitive ritualistic behaviors or mental acts ${ }^{[1,2]}$. Epidemiologic studies have revealed that the lifetime prevalence of obsessive-compulsive disorder ranges from $2 \%$ to $3 \%$ around the world ${ }^{[3,4]}$. The disease incurs significant mental health costs and negatively affects the individual's quality of life due to impaired social and occupational functioning ${ }^{[3,5]}$. Relatively little is known about the etiology and pathogenesis of obsessive-compulsive disorder. Many investigations have attempted to clarify the etiopathogenesis of this disorder and assessed the role of genetic, environmental and immunologic factors, as well as infectious diseases ${ }^{[3,5-7]}$.

The hypothesis that Toxoplasma gondii, the causative agent of toxoplasmosis infection, may be responsible for psychiatric disorders has been frequently discussed in recent years. It has been suggested that infectious agents can trigger neuropsychiatric symptoms by directly affecting neurons and brain structures, or by the stimulation of a specific immune response and the subsequent release of proinflammatory cytokines and neurotoxic factors. However, the exact mechanism by which $T$. gondii infection modifies cognition and behaviour is not fully understood ${ }^{[8-11]}$.

$T$. gondii is an obligate intracellular parasite that infects approximately 30\% of the world population $^{[12]}$. Domestic cats and other felines are the definitive hosts in toxoplasmosis, while human beings and other mammals are intermediate hosts. Humans are generally infected by consumption of raw or undercooked meat containing tissue cysts or by ingestion of unwashed raw vegetables, foods and drinking water contaminated with oocysts shed by infected cats ${ }^{[13]}$. Furthermore, contact with contaminated soil, blood transfusion, organ transplantation and vertical transmission during pregnancy are other ways of $T$. gondii transmission. In the acute phases of the infection, actively 
proliferating forms of the parasite called tachyzoites are usually seen in almost every tissue of the body. Then, tachyzoites differentiate into slowly replicating bradyzoite forms which cluster to form tissue cysts, mainly in the brain and muscle. In the latent stage of the infection, parasites may persist within these tissue cysts throughout the life of the host ${ }^{[12-14]}$.

Until recently, latent infection with $T$. gondii in immunocompetent or seropositive patients has been usually considered as asymptomatic or relatively benign. However, it is now suggested that T. gondii may induce cognitive and behavioral changes in infected rats and humans ${ }^{[8,15,16]} . T$. gondii has a specific tropism for brain tissue and the cerebral hemispheres, basal ganglia, cerebellum and hippocampus are the most frequently affected regions in the brain ${ }^{[5,16]}$. The findings from animal models have indicated that behaviour and personality alterations may occur as a result of the local inflammatory reaction induced by the dormant cysts in the brain tissue ${ }^{[10]}$. The direct stimulation of inflammatory cytokines may initiate a cascade of events leading to neuroinflammation and neurodegeneration in the central nervous system $^{[12,17]}$. On the other hand, the genome of the parasite contains genes encoding aromatic amino acid hydroxylases that directly affect dopamine biosynthesis, and $T$. gondii has been shown to increase dopamine levels in the brain, as well as to influence serotonin, gamma-aminobutyric acid and glutamate pathways ${ }^{[11,16-18]}$. The enhanced production of dopamine in conjunction with a disturbance in the concentration of other neurotransmitters is known to play an important role in the pathogenesis of psychological disturbances $^{[11,15]}$.

Recently published studies have examined the relationship between latent $T$. gondii infection and various psychiatric disorders, such as bipolar disorder, schizophrenia, depression and anxiety disorder ${ }^{[15,19]}$. A substantial literature suggests that $T$. gondii seropositivity status seems to be mostly associated with schizophrenia ${ }^{[19]}$. However, the probable causal relationship between latent toxoplasmosis and obsessive-compulsive disorder has been investigated in a very limited number of studies ${ }^{[15,17,18,20-24]}$. In addition, available data are still controversial. Meanwhile, it should be noted that the diagnosis of latent infection is based on the detection of serum immunoglobulin $G$ antibodies against $T$. gondii (anti- $T$. gondii $\mathrm{IgG}$ ), as it is not possible to detect encysted parasites in humans, except postmortem investigations ${ }^{[16]}$.

The aim of this study was to investigate $T$. gondii prevalence in patients with obsessive-compulsive disorder and in healthy controls living in Isparta region of Turkey by using serologic tests, and to assess the association between $T$. gondii and this disorder.

\section{MATERIALS and METHODS}

This cross-sectional study was carried out at the Department of Psychiatry in collaboration with the Department of Medical Microbiology, Suleyman Demirel University Research and Practice Hospital between January 2019 and February 2020. Ethical approval was obtained from the Ethics Committee of the Faculty of Medicine, Suleyman Demirel University before the study commenced. The content of the study was explained to the participants, and written informed consent was taken from those agreeing to take part.

\section{Patients and Controls}

Subjects with severe chronic disease, recent infectious disease, immunodeficiency, autoimmune disease, malignancy, comorbid psychiatric disease, cognitive impairment or dementia were excluded from the study. Thirty-eight patients with obsessive-compulsive disorder and 48 healthy controls with similar age and sex distribution were included in the study. In the patient group, the diagnosis of obsessive-compulsive disorder was established by an experienced psychiatrist according to Diagnostic and Statistical Manual of Mental Disorders, Fifth Edition, Text Revision (DSM-5-TR) criteria via independent clinical interview. The Yale-Brown Obsessive Compulsive Scale (Y-BOCS) and the Hamilton Depression Rating Scale (HDRS) were also administered to evaluate the severity of obsessive-compulsive disorder and depression, respectively. The control group consisted of healthy volunteers with no personal or family history of psychiatric disorder attending outpatient clinics of the same hospital for routine health check-up. Data regarding pro- 
bable risk factors for $T$. gondii infection (current or past living in a rural region, contact with soil; gardening or agricultural activities, contact with cats; having a cat at home or playing closely with cats, consumption of raw or undercooked meat and consumption of unwashed raw vegetable or fruit), sociodemographic data (age, sex, education level, socioeconomic status) and clinical features (duration of illness, lifetime total duration of medication, family history, suicide attempt history, Y-BOCS and HDRS) were recorded after clinical interviews.

\section{Laboratory Analysis}

About $5 \mathrm{~mL}$ venous blood was taken from each subject, and then centrifuged prior to testing. The serum anti- $T$. gondii IgM and IgG levels were determined by using an automated chemiluminescence immunoassay method (Roche Cobas e601 analyzer, Roche Diagnostics, Mannheim, Germany). Anti- $T$. gondii IgM test result of $\geq 1.0$ $\mathrm{COI}$ and anti- $T$. gondii IgG test result of $\geq 3 \mathrm{IU} /$ $\mathrm{mL}$ were regarded as positive, according to the manufacturer's guidelines. All positive results were retested in duplicate. A positive test result for anti- $T$. gondii IgG antibody indicated past infection with $T$. gondii, while anti- $T$. gondii IgM positivity was considered as a recent primary infection.

\section{Statistical Analysis}

Statistical analysis was performed using SPSS v. 22 (SPSS Inc., Chicago, Illinois, USA). The Kolmogorov-Smirnov test was used to evaluate the normality of the data. Accordingly, Student's $\mathrm{t}$-test or the Mann-Whitney $\mathrm{U}$ test was used to compare the differences in continuous variables between groups. The chi-square test with Bonferroni correction was used for categorical variables. Odds ratios (OR) and 95\% confidence intervals (CIs) were calculated. Results were expressed as frequencies and percentages, or mean \pm standard deviation. A p value of less than 0.05 was considered statistically significant.

\section{RESULTS}

Comparisons of sociodemographic data, possible risk factors for $T$. gondii infection, $T$. gondii seropositivity status and clinical features in the patient and control groups are depicted in Table 1.
None of the participants showed anti- $T$. gondii IgM seropositivity. Anti- $T$. gondii IgG positivity was found in $6(15.8 \% ; \mathrm{CI}: 7.4-30.4)$ of the 38 patients with obsessive-compulsive disorder and in $9(18.8 \%$; CI:10.2-31.9) of the 48 control subjects (Table 1). No statistically significant correlation was determined between $T$. gondii IgG seropositivity and obsessive-compulsive disorder $(\mathrm{OR}=0.813$; CI:0.261-2.525, $\mathrm{p}=0.719)$. In terms of anti- $T$. gondii IgG titers (serointensity), the difference was not statistically significant $(p=$ 0.589 ) between seropositive patients (201.23 \pm $63.79 \mathrm{IU} / \mathrm{mL}$ ) and seropositive controls (263.69 $\pm 267.71 \mathrm{IU} / \mathrm{mL}$ ) (data not shown).

There was no significant difference between the patient and control groups in terms of age, sex, education level, socioeconomic status, cigarette smoking, residence in rural region, contact with soil, contact with cats, raw or undercooked meat consumption, and unwashed raw vegetable or fruit consumption ( $p>0.05)$ (Table 1).

Seropositive patients were significantly $(p=$ 0.001 ) older than seronegative patients (Table $2)$. In the study population $(n=86)$, there were significant differences in the age $(p=0.001)$, education level $(p=0.001)$, socioeconomic status $(p=0.007)$, residence in rural region $(p=0.013)$ and unwashed raw vegetable or fruit consumption $(p=0.030)$ between seropositive participants $(n=$ 15) and seronegative participants $(n=71)$ (Table 2). Advanced age, low education level, low socioeconomic status, living in a rural region and consumption of unwashed raw vegetable or fruit were found to be the significant risk factors for T. gondii infection in our study population.

\section{DISCUSSION}

In the last two decades, numerous studies have been conducted to investigate the possible causal relationship between latent $T$. gondii infection and psychiatric disorders ${ }^{[9,11,19]}$. The parasite's ability to affect neurotransmitter pathways and immune response has drawn the attention of many researchers in this field. Among the psychiatric disorders, the role of $T$. gondii has been studied most extensively in the etiology of schizophrenia, and significantly increased levels of anti- $T$. gondii $\operatorname{IgG}$ antibodies were frequently 


\begin{tabular}{|c|c|c|c|}
\hline & Patient group $(n=38)$ & Control group $(n=48)$ & p \\
\hline $\begin{array}{l}\text { Age (years) } \\
18-29 \text { years } \\
30-49 \text { years } \\
>50 \text { years }\end{array}$ & $\begin{array}{c}32.45 \pm 9.54 \\
15(39.5) \\
21(55.2) \\
2(5.3)\end{array}$ & $\begin{array}{c}34.1 \pm 13.61 \\
27(56.2) \\
15(31.3) \\
6(12.5)\end{array}$ & 0.526 \\
\hline Sex (Male/Female) & $16(42.1) / 22(57.9)$ & $21(43.8) / 27(56.2)$ & 0.878 \\
\hline $\begin{array}{l}\text { Education level } \\
\text { Primary school } \\
\text { High school } \\
\text { Higher education }\end{array}$ & $\begin{array}{c}4(10.5) \\
11(29) \\
23(60.5)\end{array}$ & $\begin{array}{c}7(14.6) \\
16(33.3) \\
25(52.1)\end{array}$ & 0.714 \\
\hline $\begin{array}{l}\text { Socioeconomic status } \\
\text { Low } \\
\text { Middle } \\
\text { High }\end{array}$ & $\begin{array}{c}4(10.5) \\
33(86.9) \\
1(2.6)\end{array}$ & $\begin{array}{c}12(25) \\
31(64.6) \\
5(10.4)\end{array}$ & 0.060 \\
\hline Cigarette smoking & $16(42.1)$ & $14(29.2)$ & 0.211 \\
\hline Residence in rural region & $12(31.6)$ & $16(33.3)$ & 0.863 \\
\hline Contact with soil & $13(34.2)$ & $22(45.8)$ & 0.276 \\
\hline Contact with cats & $16(42.1)$ & $14(29.2)$ & 0.211 \\
\hline Raw or undercooked meat consumption & $6(15.8)$ & $2(4.2)$ & 0.065 \\
\hline Unwashed raw vegetable/fruit consumption & $6(15.8)$ & $11(22.9)$ & 0.410 \\
\hline Anti-T. gondii IgG positivity & $6(15.8)$ & $9(18.8)$ & 0.719 \\
\hline Anti-T. gondii IgM positivity & $0(0)$ & $0(0)$ & \\
\hline Duration of illness (years) & $10.46 \pm 9.2$ & - & \\
\hline Lifetime total duration of medication (years) & $4.67 \pm 4.97$ & - & \\
\hline Family history & $13(34.2)$ & - & \\
\hline Suicide attempt history & $9(23.7)$ & - & \\
\hline Yale Brown rating scale score & $19.84 \pm 9.36$ & - & \\
\hline Hamilton depression rating scale score & $15.39 \pm 6.28$ & - & \\
\hline
\end{tabular}

*Values are expressed as $\mathrm{n}(\%)$ or mean \pm SD.

found in the serum of patients with schizophrenia $^{[11,19]}$. However, a small number of studies examined the probable association between $T$. gondii and obsessive-compulsive disorder, and inconsistent results were reported across the studies ${ }^{[15,17,18,20-24]}$. In this regard, we aimed to analyze whether obsessive-compulsive disorder is correlated with $T$. gondii seropositivity in our study population in Isparta, Turkey.

Preclinical and clinical studies have shown that dopaminergic and serotonergic neurotransmission systems play a prominent role in the genesis and maintenance of obsessive-compulsive symptoms ${ }^{[1,3,6,21]}$. In addition, the basal ganglia, which are densely innervated by dopaminergic fibres, are considered as an important source for the symptoms of obsessive-compulsive disorder ${ }^{[6,21]}$. Similarly, latent toxoplasmosis significantly influences dopaminergic, serotonergic and other neurotransmitter systems, and the basal ganglia are one of the most commonly affected anatomic regions of the brain in infected individuals ${ }^{[5,11,16-18,25]}$. These similarities have led to the notion that $T$. gondii may trigger the development of obsessive compulsive disorder. Hence, the hypothesis that T. gondii is a possible cause of obsessive-compulsive disorder seems quite reasonable.

In a study conducted in Turkey, the seropositivity rate $(47.6 \%)$ for anti- $T$. gondii IgG antibodies in 42 patients with obsessive-compulsive disorder 
Table 2. Comparison of sociodemographic features and possible risk factors for $T$. gondii infection in seropositive/seronegative patients and in all seropositive/seronegative participants

\begin{tabular}{|c|c|c|c|c|c|c|}
\hline & $\begin{array}{l}\text { Seropositive } \\
\text { patients } \\
(n=6)\end{array}$ & $\begin{array}{l}\text { Seronegative } \\
\text { patients } \\
(n=32)\end{array}$ & $p$ & $\begin{array}{l}\text { All seropositive } \\
\text { participants } \\
(n=15)\end{array}$ & $\begin{array}{l}\text { All seronegative } \\
\text { participants } \\
(n=71)\end{array}$ & p \\
\hline $\begin{array}{l}\text { Age (years) } \\
18-29 \text { years } \\
30-49 \text { years } \\
>50 \text { years }\end{array}$ & $\begin{array}{c}45.33 \pm 10.6 \\
0(0) \\
4(66.7) \\
2(33.3)\end{array}$ & $\begin{array}{c}30.03 \pm 7.23 \\
15(46.9) \\
17(53.1) \\
0(0)\end{array}$ & 0.001 & $\begin{array}{c}51.13 \pm 15.25 \\
1(6.7) \\
6(40) \\
8(53.3)\end{array}$ & $\begin{array}{c}29.62 \pm 6.7 \\
41(57.7) \\
30(42.3) \\
0(0)\end{array}$ & 0.001 \\
\hline Sex (Female) & $4(66.7)$ & $18(56.3)$ & 0.635 & $9(60)$ & $40(56.3)$ & 0.795 \\
\hline $\begin{array}{l}\text { Education level } \\
\text { Primary school } \\
\text { High school } \\
\text { Higher education }\end{array}$ & $\begin{array}{c}2(33.3) \\
1(16.7) \\
3(50)\end{array}$ & $\begin{array}{c}2(6.2) \\
10(31.3) \\
20(62.5)\end{array}$ & 0.134 & $\begin{array}{l}7(46.7) \\
3(20) \\
5(33.3)\end{array}$ & $\begin{array}{c}4(5.6) \\
24(33.8) \\
43(60.6)\end{array}$ & 0.001 \\
\hline $\begin{array}{l}\text { Socioeconomic status } \\
\text { Low } \\
\text { Middle } \\
\text { High }\end{array}$ & $\begin{array}{c}2(33.3) \\
4(66.7) \\
0(0)\end{array}$ & $\begin{aligned} 2 & (6.2) \\
29 & (90.7) \\
1 & (3.1)\end{aligned}$ & 0.133 & $\begin{array}{c}7(46.7) \\
8(53.3) \\
0(0)\end{array}$ & $\begin{array}{c}9(12.7) \\
56(78.9) \\
6(8.4)\end{array}$ & 0.007 \\
\hline Cigarette smoking & $2(33.3)$ & $14(43.8)$ & 0.635 & $2(13.3)$ & $28(39.4)$ & 0.054 \\
\hline Residence in rural region & $2(33.3)$ & $10(31.2)$ & 0.920 & $9(60)$ & $19(26.8)$ & 0.013 \\
\hline Contact with soil & $2(33.3)$ & $11(34.4)$ & 0.961 & $7(46.7)$ & $28(39.4)$ & 0.605 \\
\hline Contact with cats & $3(50)$ & $13(40.6)$ & 0.670 & $7(46.7)$ & $23(32.4)$ & 0.292 \\
\hline $\begin{array}{l}\text { Raw or undercooked meat } \\
\text { consumption }\end{array}$ & $1(16.7)$ & $5(15.6)$ & 0.949 & $2(13.3)$ & $6(8.5)$ & 0.554 \\
\hline $\begin{array}{l}\text { Unwashed raw vegetable/ } \\
\text { fruit consumption }\end{array}$ & $2(33.3)$ & $4(12.5)$ & 0.199 & $6(40)$ & $11(15.5)$ & 0.030 \\
\hline
\end{tabular}

has been found to be significantly higher than the rate (19\%) in 100 healthy volunteers ${ }^{[21]}$. The authors have concluded that there might be a causal relationship between latent toxoplasmosis and the etiology of obsessive-compulsive disorder. In a cross-sectional study from Czechia, Flegr and Horacek ${ }^{[15]}$ have reported that individuals with toxoplasmosis had approximately a 2.5 times higher odds of obsessive-compulsive disorder. Another Turkish study has revealed a significant correlation between anti- $T$. gondii $\operatorname{IgG}$ positivity and obsessive-compulsive disorder, and it has been observed that IgG positive subjects had a 4.8-fold greater risk of obsessive-compulsive disorder compared to IgG negative subjects ${ }^{[18]}$.

In contrast to these findings, in the present study, we could not find a statistically significant difference between the patient group and control group in terms of association between $T$. gondii seropositivity and obsessive-compulsive disorder.
The results suggested that $T$. gondii infection had no effect on the development of obsessive-compulsive disorder in our sample group. The anti- $T$. gondii IgG positivity rate (18.8\%) in the control group was comparable to the results (17.5\%$69.5 \%$ ) reported in $T$. gondii seroprevalence studies in our country ${ }^{[26,27]}$. However, seropositivity rate $(15.8 \%)$ in the patient group was found to be lower than the expected seroprevalence rates. This low seropositivity rate could have been arisen from the contamination obsessions and cleaning compulsions of some patients or from preferring to stay at home in a controllable environment that lead to reduced risk of exposure to the parasite. In line with our results, in a sample including 42 patients with pediatric obsessive-compulsive disorder and 45 healthy individuals, Memik et al. found no statistically significant association between $T$. gondii seropositivity and obsessive-compulsive disorder ${ }^{[20]}$. Furthermore, in 
two studies with smaller sample sizes performed in China, no significant relationship between $T$. gondii seroprevalence and obsessive-compulsive disorder has been reported ${ }^{[22,23]}$.

The causes for these inconsistent findings across the studies are not known with certainty, but this situation may result from differences in the serological techniques, differences in the seroprevalence of $T$. gondii infection, the timing of infection, or differences in the genetic features of the subjects. On the other hand, as also indicated in previous papers, there are some difficulties with the hypothesis that $T$. gondii may be a possible cause of obsessive-compulsive disor$\operatorname{der}[9,20,25]$. The major limitation is the apparent epidemiological inconsistency. The prevalence of the infection varies widely by geographic location, nutritional habits, socioeconomic status and cultural traditions ${ }^{[12,14]}$. Countries with a higher seropositivity rates of toxoplasmosis, such as Brazil (50\%), France (54\%) and Germany (63\%), do not display a corresponding increased obsessive-compulsive disorder prevalence ${ }^{[4,28,29]}$. Obsessive-compulsive disorder, unlike toxoplasmosis, does not exhibit marked geographic variation in prevalence. Assuming that an association exists between T. gondii and obsessive-compulsive disorder, the parasite can only induce this disease in a fraction of individuals it infects. Moreover, it is known that the prevalence of $T$. gondii infection increases with age, but there is no such progress in obsessive-compulsive disorder ${ }^{[12,20,25]}$. The disease has usually a bimodal age of onset (childhood and adolescent), and disease onset in older adults has rarely been reported ${ }^{[6,25]}$. Another difficulty with the hypothesis is that obsessive-compulsive disorder, like other psychiatric disorders, is an etiologically complex condition resulting from multiple interacting factors, and that it cannot be attributed to a single cause $e^{[5,9,20]}$. Finally, if the association between $T$. gondii infection and obsessive-compulsive disorder is approved, specific anti-parasitic therapy may prevent the development of obsessive-compulsive disorder. However, there has not yet been any clinical study that precisely evaluated the efficacy of anti-parasitic therapy against toxoplasmosis in patients with obsessive-compulsive disorder ${ }^{[6]}$.
The current study has some limitations that should be considered when interpreting the results. First, this was a single-center study and had relatively limited numbers of patients and controls. Second, medications or other unpredictable confounding factors could influence the antibody levels in the patient group. It should be noted, however, that an automated and standardized laboratory method having high sensitivity and specifity was used to determine the serum antibody levels.

In conclusion, we found no evidence that latent $T$. gondii infection is associated with obsessive-compulsive disorder. The presence of conflicting data on the relationship between latent $T$. gondii infection and obsessive-compulsive disorder highlights the need for further studies with larger sample sizes.

\section{ETHICS COMMITTEE APPROVAL}

Ethical approval for the study was obtained from the Ethics Committee of the Faculty of Medicine, Suleyman Demirel University, Isparta, Turkey (Decision no: 72867572.050.01.04 299119, Date: 13.12.2018).

\section{CONFLICT of INTEREST}

The authors declare that they have no conflict of interest.

\section{AUTHORSHIP CONTRIBUTIONS}

Concept and Design: MCS, FK

Data Collection or Processing: MCS, FK, AD, BÖ

Analysis/Interpretation: MCS, FK, AD, BÖ

Literature Search: AD, BCA, ESC

Writing: MCŞ, FK

Final Approval: All of authors

\section{REFERENCES}

1. Stein DJ. Obsessive-compulsive disorder. Lancet 2002;360(9330):397-405.

2. American Psychiatric Association. Diagnostic and statistical manual of mental disorders (DSM-V). $5^{\text {th }}$ ed. Washington DC; 2013.

3. Abramowitz JS, Taylor S, McKay D. Obsessive-compulsive disorder. Lancet 2009;374:491-9. 
4. Fontenelle LF, Mendlowicz MV, Versiani M. The descriptive epidemiology of obsessive-compulsive disorder. Prog Neuropsychopharmacol Biol Psychiatry 2006;30(3):32737.

5. Lamothe H, Baleyte IM, Smith P, Pelissolo A, Mallet L. Individualized Immunological data for precise classification of OCD patients. Brain Sci 2018;8(8):149.

6. Gerentes M, Pelissolo A, Rajagopal K, Tamouza R, Hamdani N. Obsessive-compulsive disorder: autoimmunity and neuroinflammation. Curr Psychiatry Rep 2019;21(8):78.

7. Brander G, Pérez-Vigil A, Larsson H, Mataix-Cols D. Systematic review of environmental risk factors for obsessive-compulsive disorder: a proposed roadmap from association to causation. Neurosci Biobehav Rev 2016;65:36-62.

8. Yolken RH, Torrey EF. Are some cases of psychosis caused by microbial agents? A review of the evidence. Mol Psychiatry 2008;13(5):470-9.

9. Fekadu A, Shibre T, Cleare A/. Toxoplasmosis as a cause for behaviour disorders-overview of evidence and mechanisms. Folia Parasitol 2010;57(2):105-13.

10. Flegr J. How and why Toxoplasma makes us crazy. Trends Parasitol 2013;29(4):156-63.

11. Yüksel $P$, Kocazeybek $B$. Do microorganisms have a role in neuropsychiatric diseases? FLORA 2013;18(2):59-65.

12. Montoya JG, Liesenfeld O. Toxoplasmosis. Lancet 2004;363(9425):1965-76.

13. Dubey JP. The history of Toxoplasma gondii-The First 100 Years. J Eukaryot Microbiol 2008;55(6):467-75.

14. Halonen SK, Weiss LM. Toxoplasmosis. Handb Clin Neurol 2013;114:125-45.

15. Flegr J, Horáček J. Toxoplasma-infected subjects report an obsessive-compulsive disorder diagnosis more often and score higher in Obsessive-Compulsive Inventory. Eur Psychiatry 2017;40:82-7.

16. McConkey GA, Martin HL, Bristow GC, Webster JP. Toxoplasma gondii infection and behaviour - location, location, location? J Exp Biol 2013;216(Pt 1):113-9.

17. Miman Ö, Özcan Ö, Ünal S, Atambay M. Toxoplasma gondii - obsessive-compulsive disorder relationship: is it different in children? Nord J Psychiatry 2018;72(7):501-5.

18. Akaltun i, Kara SS, Kara T. The relationship between Toxoplasma gondii IgG antibodies and generalized anxiety disorder and obsessive-compulsive disorder in children and adolescents: a new approach. Nord J Psychiatry 2018;72(1):57-62.

19. Sutterland AL, Fond $G$, Kuin A, Koeter MWI, Lutter $R$, van $\mathrm{Gool} T$, et al. Beyond the association. Toxoplasma gondii in schizophrenia, bipolar disorder, and addiction: systematic review and meta-analysis. Acta Psychiatr Scand 2015;132(3):161-79.
20. Memik NÇ, Tamer GS, Unver H, Gündoğdu ÖY. The relationship between pediatric obsessive compulsive disorder and Toxoplasma gondii. J Obsessive Compuls Relat Disord 2015;7(C):24-8.

21. Miman O, Mutlu EA, Ozcan O, Atambay M, Karlidag R, Unal S. Is there any role of Toxoplasma gondii in the etiology of obsessive-compulsive disorder? Psychiatry Res 2010;177(1-2):263-5.

22. Xiao $Y$, Yin I, Jiang $N$, Xiang $M, \operatorname{Hao} L, L u H$, et al. Seroepidemiology of human Toxoplasma gondii infection in China. BMC Infect Dis 2010;10:4.

23. Cong W, Dong W, Bai L, Wang X-Y, Ni X-T, Qian A-D, et al. Seroprevalence and associated risk factors of Toxoplasma gondii infection in psychiatric patients: a case-control study in eastern China. Epidemiol Infect 2015;143:3103-9.

24. Zaki WM, Hofdi RY, Shebiley AA, Saadi ZA, Ageel AH. Seroprevalence of Toxoplasma gondii infection and its associated risk factors in neuropsychiatric patients in Jazan Province, Saudi Arabia. J Egypt Soc Parasitol 2016;46(3):467-74.

25. Taboas W, McKay D, Taylor S. Does Toxoplasma gondii play a role in obsessive-compulsive disorder? Psychiatry Res 2012;198(1):176-7.

26. Kolören $Z$, Dubey JP. A review of toxoplasmosis in humans and animals in Turkey. Parasitology 2020;147(1):12-28.

27. Malatyalı E, Yıldız I, Tileklioğlu E, Ertabaklar H, Ertuğ S. Retrospective analysis of Toxoplasma gondii serology results from Adnan Menderes University Faculty of Medicine Parasitology Laboratory from 2007 to 2017. Turkiye Parazitol Derg 2019;43(1):1-4.

28. Flegr J, Prandota J, Sovičková M, Israili ZH. Toxoplasmosis - A Global Threat. Correlation of latent Toxoplasmosis with specific disease burden in a set of 88 countries. PLoS One 2014;9(3):e90203.

29. Fullana MA, Vilagut $G$, Rojas-Farreras $S$, Mataix-Cols D, de Graaf $R$, Demyttenaere $K$, et al. Obsessive-compulsive symptom dimensions in the general population: results from an epidemiological study in six European countries. I Affect Disord 2010;124(3):291-9.

\section{Address for Correspondence/Yazıșma Adresi}

Doc. Dr. Mümtaz Cem ȘiRiN

Süleyman Demirel Üniversitesi Tıp Fakültesi

Tibbi Mikrobiyoloji Anabilim Dalı,

Isparta-Türkiye

E-mail: drmcemsirin@yahoo.com 